\title{
An unfortunate confluence of motives: Fast food as economic development
}

\author{
Review by Parke Troutman* \\ San Diego, California
}

Review of Supersizing Urban America: How Inner Cities Got Fast Food with Government Help, by Chin Jou. (2017). Published by University of Chicago Press. Available as hardcover and ebook; 248 pages. Publisher's website: http://www.press.uchicago. edu/ucp/books/book/chicago/S/bo14193313.html

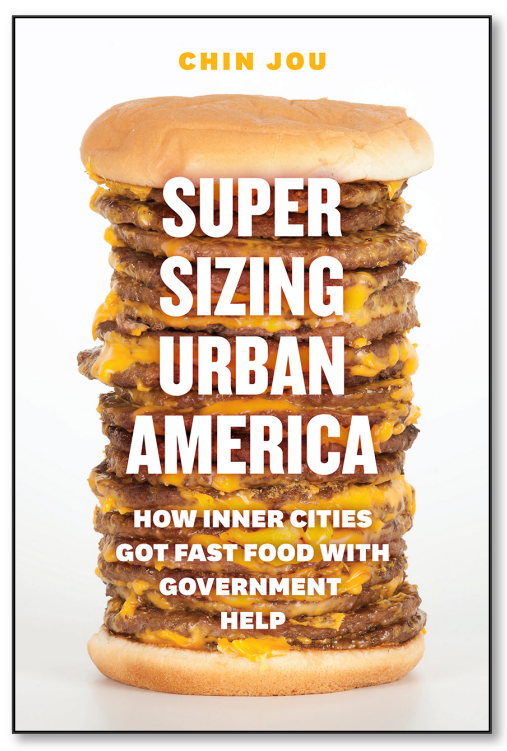

Submitted July 3, 2017 / Published online November 13, 2017

Citation: Troutman, P. (2017). An unfortunate confluence of motives: Fast food as economic development [Book review]. Journal of Agriculture, Food Systems, and Community Development. Advance online publication. http://dx.doi.org/10.5304/jafscd.2017.074.011

Copyright (C) 2017 by New Leaf Associates, Inc.

$\mathrm{T}$ he food movement keeps returning to a handful of themes: the industrialization of food, the promise and challenges of local food, the shenanigans of large corporate players and the like. Rare is a work like Chin Jou's Supersizing Urban America, which explores a facet of food-one that has serious health consequences-in a potentially new and intriguing way by linking local food environments to a relatively obscure federal program.

* Parke Troutman received his $\mathrm{PhD}$ in sociology from the University of California, San Diego. He has worked on campaigns ranging from easing city restrictions on community gardens to improving the federal Summer Food Service Program for low-income children. He currently does policy analysis and community training on local food environments for a local health department. He can be reached at parke.troutman@gmail.com.
The majority of the book is a history of how fast food franchises came to dominate the urban landscape. Jou claims that as late as the 1960s, African Americans were eating better than whites (a claim with so many implications that it deserves a book in its own right). By the early 1970s, the Nixon Administration was looking for explicitly capitalist - that is, decidedly noncommuniststrategies to revitalize urban neighborhoods torn apart by the violence of the ' 60 s. It focused on promoting black entrepreneurship.

Simultaneously, fast food corporations were reaching a saturation point in the suburban and highway markets where they had grown so explosively for almost two decades. Indeed, the revenue from those stores was showing vulnerability to rising gas prices, as the first oil shock made clear. Fast 
food corporations knew they needed new markets, preferably not dependent on cars. Urban areas were a natural place to look but were seen as high cost/low return gambles.

The franchise model, in which a local person invests heavily for the right and technical knowhow to open a brand-name store, became a bridge between the Nixon Administration's and corporate fast food's goals. The resulting mix of motivations and policies led to a one-two dance step. Franchising allowed companies like McDonald's to transfer risk to local entrepreneurs, and loan guarantees allowed a significant chunk of that risk to be transferred again to the federal government. The result was an effective model of growth, made all the more so by the increasing vacuum of supermarket chains abandoning inner-city areas.

Although partially stymied by poor recordkeeping (federal) and limited access to files (corporate), this is a fascinating story. Jou approaches it from different angles, including not only that of the corporations and the federal government but also of franchisees and residents. The result is compelling. Jou only teases, however, at the moral ambiguity of everyone's actions. At the beginning of the period covered, what is now called the obesity epidemic was not so alarming as it is today. As the story marches forward through the decades, the destructive effects of unhealthy diets became increasingly obvious. The narrative acknowledges this, almost in passing, but does not squarely face how consumers, corporate leadership and government staff reconciled, or continue to reconcile, the consumption of fast food with its long-term consequences.This is a missed opportunity as it has implications for how we conceptualize urban food environments, especially the notion of a food apartheid.

The introduction through chapter five of this brief book cover the history and rise of urban fast food. These are its strength. When the book turns toward recent policies and possible reforms, however, it loses momentum. The review of more recent government policies and possible innovative approaches feels more obligatory than compelling. It is paralyzed by inconsistencies in the literature and the modesty of new proposals. Jou's response to the lack of a clear direction forward leads to an unsatisfactory jump in the final pages to the conclusion that the only way food problems will be genuinely solved is by tackling inequality. If that were true, then it is not clear why someone should read this book instead of one on eliminating economic disparities.

The introduction alerts us that the conclusions might be underwhelming when it notes that others have criticized the federal government for supporting fast food, but then rejects that as a focus for the book, saying, "Rather, this book draws attention to the history of a slice of America's contemporary food environment..." (p. 6). Drawing attention to an issue is rewarded in academia, but if you're a legislative staffer for whom unhealthy food is only one of two dozen issues you have to track, if you're a nonprofit advocate whose schedule just got upended because that legislative staffer can only give you fifteen minutes during what was to be a conference call you were to facilitate, or if you're a resident who has to deal with the reality of your kids getting hungry three times a day, then you need more than having attention drawn an issue.

Realistically speaking, however, academics are not well positioned to map out practical political campaign strategies. What they can do-what others lack the time, analytical tools, and distance to do-is to analyze how ambitious proposals must be to get us to the change we want. If community gardens, farmers markets, improved school meals, soda taxes, etc., are not enough, what else needs to be done?

The limits of the last several chapters aside, by highlighting a government loan program that can be reformed, the book could spur creative strategies that go beyond the romanticized "community garden and farmers market" drumbeat that is still so often suggested as a way of improving local food environments. With any luck, Jou's work will start to build momentum around questions of the appropriate role of the federal government in helping local food businesses profitably sell healthier foods, a question made all the more urgent by the increasingly fierce supermarket price wars now underway. 